\title{
"Thou shalt bid thy fair hands rove": L. E. L.'s Wooing of Sex, Pain, Death and the Editor
}

Cynthia Lawford

Independent Scholar, Hertfordshire

So what if Letitia Landon had three illegitimate children by William Jerdan? What difference does the discovery of the affair make for our reading of L. E. L.'s poetry? This essay begins to explore these questions with regard to her love poems, many of which culminate in a desire for death even greater than that voiced for the absent beloved. We have been disinclined to believe in the authenticity of the poems' fatal passions and naturally require more evidence before we can assume that any of their intensity is related to Landon's feelings for the bibulous Literary Gazette editor. Through examining a number of Landon's early, sexually daring poems and her relationship with Jerdan at the time of their writing, this essay provides some of that evidence and discusses the part these works likely played in the evolution of this literary and sexual relationship. According to Landon's theory, genius had to devote its grand soul to an inferior being to experience the torment essential for producing literary works of the highest order. Landon viewed her affair with the editor as a means to a greater end: the poems themselves, including, not incidentally, their publication and promotion.

Sneers about Letitia Landon's poetry have often accompanied sneers about her life (1802-1838). Much of the commentary she has received in the last century has left behind the impression that Landon was a silly young woman who filled up too many pages of poetry with her dreams of unreal love and more unreal death over lost love. She had no idea of authentic passion and pain because she had no experience of them. Taking account of the scholarship to date in her 1999 article, Tricia Lootens presents some questions which demonstrate how our understanding of Landon's life story is fundamental to our perception of her work: 
Landon was concealing truth in order to succeed in the market place, she continually insisted: but what truth? Was she the devoted victim of her audience's whims, or the manipulator of their desires? Did her love poetry confess the passion of a real Sappho, albeit in snub-nosed Brompton form, and incompletely disguised as a "professional"? Or was it acutely the work of a hypocrite, an adept at emotional artifice who marketed expressions of a passion she did not feel? Such questions were intrinsic to the "mystery" of $L$. E. L. At the first extreme, she could be seen as ridiculous or pitiable, but an "honest" woman; at the second, as a competent literary businesswoman, but emotionally disingenuous.

The truth is, despite her work's daring emotional honesty, Landon was no "honest" woman. As new evidence has shown, almost the whole of Landon's literary career was spent concealing her sexual affair with the editor the Literary Gazette, William Jerdan, whom all three of Landon's illegitimate children believed to be their father: Ella Stuart, Fred Stuart, and Laura Landon (Lawford 36-37). Allowing the evidence to transform our understanding of Landon and her work is not easy, given the weight of published discourse that has long discouraged our thinking of Landon as anyone's sexual partner during the nearly two decades of her life as a single writer. Nineteenth-century readers could have believed she was "fallen" but did not want to; late twentiethcentury readers wanted to believe it but could not. "There is no proof that L. E. L. ever had a lover by day or night, let alone several. One would like her rather better if she had," Germaine Greer admits for all of us in Slip-shod Sibyls (1995), "but she seems, however reckless in her superficial manner, to have been deeply reserved about any act of physical committal" (311). Now that we know she was not reserved, perhaps liking her better will help us interrogate our learned instincts that had detected "hollowness" in her poetry where more than likely there is none (Leighton 68; Mellor 120-21; Stephenson 122). Knowledge of the affair demands an end to easy acceptance of all the charges of superficiality laid at Landon's words about love. This knowledge requires that we ask why we either refused to trust her poetry's extremes of ecstasy, misery, and yearning that so thrilled her contemporaries or why we could consider them only under the category of the "ridiculous or pitiable."

Of course, Landon's involvement in this affair -- and perhaps others -during most of her professional career does not necessarily mean the 
poems express authentic passion. I think that they do and that much of that passion was directed toward Jerdan. Perhaps she wrote most of her love poems with, among other concerns, his reading of them in mind. Their affair could have begun no later than 1823, given the eldest child Ella Stuart's baptism in April 1824, and it continued until at least 1834 and may have lasted until about 1837 (Lawford 36-37). I think the affair began in 1822 and much that Landon wrote in 1821 and 1822 encouraged it to begin. Here, by referring to some of her earliest and most erotically audacious work, I wish to let the affair and the love poems mutually inform one another, while giving some reasons for my conclusion that Landon wrote her feelings for Jerdan into her early love poems.

I also wish to begin to ponder what difference the affair makes to our reading of her love poetry, specifically to our reading of her ideal of the woman who loves one man to the exclusion of all other ties and interests, the woman who can find no happiness and wants no life without her man, regardless of how he treats her. Our awareness of how this ideal has harmed women historically has made it so repugnant that perhaps we have been unfairly prejudiced against examining it as a source of poetic inspiration which Landon used to fire the minds and bring tears to the eyes of men and women alike. If we are ever to appreciate the power her poetry held for her contemporaries, we must start to look seriously at how she took the sacrificial, or masochistic, eroticism of this ideal and infused it into the sentimentality of the 1820 s and 1830 s, which is not usually seen as addressing overt sexual desires.

Knowing that Landon carried on an extended affair at the risk of her reputation, and thus her career, income, and social acceptance, lends the love poetry a sense not only of authenticity but of dangerous vulnerability and often of urgency, that elevates the reader to the position of most treasured confidante - sometimes of her secret love, always of her philosophy of love. Landon wanted contemporary readers to admire and sympathize with female characters (like herself) brave enough

To yield thus to another's reign; --

To live but in another's breath - 
To double all life's powers of pain -

To die twice in another's death.

By extending their sympathy to sentiments that sometimes also seemed confided to a secret love, readers then acquiesced to Landon's deviant philosophy of woman's love without knowing for certain to what they were acquiescing, except that its deviance was mixed up with her romantic sentimentality. Her often quoted statement in the preface to The Venetian Bracelet -- "I have always sought to paint it [woman's love] self-denying, devoted, and making an almost religion of its truth" -- was supposed to sound bold, extreme, a little scary in its religiousness, not what would appeal to many except those Landon would term the "young" and "romantic" (vi-vii).

But that and similar statements hardly suggest the possibilities that the affair with Jerdan opens up. For reading Landon's love poems in the light of her affair transmogrifies what had seemed to be her ideal of woman's love, placing illicit affection, or sex outside of marriage, not only within its bounds, but at its core. The heroic sacrifices of females, more unmarried than married, that litter her poems are essentially, pleasurably, and painfully sexual. Indeed, from midnight assignations to leaving parents without their blessing, the daring sexuality of her unmarried females is fundamental to their heroism. For instance, in "Louise, Duchess of La Valliere" (1838), a poem written for her farewell edition of Fisher's Drawing Room Scrap-Book, Landon portrays the former mistress of Louis XIV praying in a convent "for love that still I feel / Sin . . . / . . / Love still too passionate and still too tender" (1819):

I kneel to pray - I only pray for him,

His coldness more than my own fault bewailing;

Night after night my weary eyes are dim

With vain fond tears o'er passion unprevailing.

I could not bear his wretchedness - my own Is but the bitter penalty of loving

As I have loved - flung at an idol's throne,

With the deep voice within the soul reproving. 
The duchess knows she violates her Christian faith with such prayers, but she cannot belie her passions or wish she had acted otherwise. For the cold king's "sake / My soul has perilled [sic] all it should have cherished." She acknowledges her guilt for what she and L. E. L. yet glorify: "Ah! never yet the heart of woman knew / Love more intense life had but one emotion." Landon hardly ever states of one of her heroines that her affection cannot be bettered, yet she would have readers assent to the supremacy of "Louisa Frances de la Baume le Blanc ... descended from the ancient noble family of De la Baume," as the duchess is named in Landon's headnote (18-19).

The rebelliousness of such an assent would not be lost on a good number of Landon's readers, many of whom could have recalled the charges of immorality that led to the much publicized failure of Edward Bulwer Lytton's 1837 play, The Duchess de la Vallière. In defiance even of her good friend Bulwer's supporters, Landon here declares the duchess a subject worth contemplating because of her immoral passions, not in spite of them. Indeed, the Duchess de la Vallière is exquisite in every respect. Upon receiving a copy of the play from Bulwer, Landon wrote back: "You have made La Valliere just a lily warmed with one touch of the rose. You are the only poet of today that knows how to write about women" (Letter to Edward Bulwer Lytton ). If Landon's poem about the duchess were not simmering enough already, add to its interpretation the real possibility that the poem is in some way about the affair with Bulwer that Landon was rumored -- but never proven -- to have had. We then have a poem where the romantic figures of a romantic past are serving as covers for Landon's expression of her own feelings to perhaps two different lovers. We have a poem that, in its various potential readings, unabashedly explodes all the standards of propriety supposed to protect the young female readers for whom Fisher's Drawing Room Scrap Book was most intended to please.

This scene of the fallen woman kneeling before her God was a favorite of Landon's. When she inserted it as part of a legend told in a series of 
tapestries hanging on the walls of the room where one of her novel's heroines will sleep, Landon could be a little more daring and exalt one more certainly damned. Fair Rosamund, mistress of Henry II, is depicted in one tapestry as

a kneeling penitent at the foot of the crucifix; her long fair hair is unbound . . . her hands are clasped, and tears are flowing fast from the quenched radiance of those shadowy eyes; no penitence can avail the still cherished sin, and no humiliation express the depths of her self-conscious degradation. She looks above, but it is in despair, not hope; she weeps, yet dares not pray, for the image of Henry is in her heart even while prostrate before the image of her Saviour.

Francesca Carrara 144-45

Rosamund has chosen a mere man over the God-made-man, so she "dares not pray" at all. The novel's heroine remains ignorant of Rosamund's sin, yet readers are made to know it and admire Rosamund as, Landon would have them believe, she had ever been admired.

No woman could own a greater love than one who sacrificed her body (not without pleasure), good name, and life, and risked her peace with God (but not her future in heaven, as Landon's God is, above all, forgiving) for the man she worships without the security of a marriage vow. Necessary to prove the strength of her adoration, her death is always in the offing and almost always preceded by a bath in the delights of melancholy. Contemporary readers could rely on L. E. L.'s producing these pleasures, direct results of the woman's sexual desire being unsatisfied or briefly satisfied only to be thwarted. Landon's love poems help us see that the sentimental poetry of her period carries a deep strain of sexual passion that lay in this melancholy which broods on lost love, refusing to accept being rejected and not letting its desires be the least diminished by rejection. Her women's sacrificial deaths then do not bespeak extreme humility. It is rather the unbending pride of their refusal to accept life without their men that leads her women to die as they do. The idea that this morbid vision might have directed the course of Landon's life could not, before evidence of the affair and children emerged, have been contemplated. Now, I think Letitia Landon valued her blood-stained ideals enough to try to love one or more men by them -- principally for the poems she 
would be inspired to write. "Destiny compels exalted minds," she wrote of De Staël as well as of Corinne. Landon could conceive of nothing higher for herself nor aim to be anything less than "The poet whose imagination draws / Its power from loving and from suffering," the poet who plunges her "Genius into misery" in order to "catch the music of the spheres / Which mortal ear was never meant to know" and to "penetrate the mysteries / Of feeling all unknown to other hearts" (“Corinne at the Cape of Misena" 252).

But despite her literary intentions, Landon's love poems are more than poems about love. Attempts to convey affection and fears and to get the absent to return, the love poems are the communicative work required to keep a relationship going. And much of this sentiment was subjected to most unsentimental deadlines. Solicited week after week in the early 1820 s by an editor seeking that which could evoke strong emotional response from readers of his poetry section, the manuscripts of L. E. L.'s love poems were yet often finished seconds before they were thrust into the hands of a waiting courier boy, who then delivered them to the Gazette office for Jerdan to give them a quick read and some punctuation before sending them on to the printer's. Under such circumstances, Landon would still try to imprint her feelings on her lover's heart.

Alas! My spirit sinks to-night;

Oh, absence is as love's twilight!

$\ldots$ in absence, will the lover

Ten thousand feverish shapes discover;

And not a care, and not a pain,

But fills the heart and racks the brain.

"The Stars" 701

12

A case can well be made that Landon was absurdly naïve to have sexually involved herself with a married man twenty years her senior with several children, who had probably long been unfaithful to his wife and would probably continue having other intrigues and other illegitimate children throughout his involvement with Landon. Jerdan also drank excessively, was forever falling into debt, and as a critic 
was not respected by his intellectual contemporaries (Hawthorne 28283; Duncan 18; Pyle 13, 90, 184-85). However, if the four volumes of Jerdan's Autobiography are to be taken as a guide, Jerdan felt for Landon perhaps the greatest love he felt for anyone. Jerdan mentions his wife of more than forty years only once in the Autobiography, causing Thomas Moore to remark in his Personal Recollections that the "inestimable" Frances Jerdan did not deserve to be "so slightingly treated" (Duncan 15). Gerald Pyle puzzles over why Frances is likewise referred to only once in the hundreds of Jerdan's letters that Pyle has read, and he wonders whether Frances and William's marriage was a "misalliance" (250).[2] In contrast, Landon is the female star and muse of the entire Autobiography. The third volume is dedicated to her and two chapters are devoted to her; she is quoted throughout and treated with by far the most emotional language. In the Autobiography's conclusion, Jerdan returns to her death (at Cape Coast Castle, in present-day Ghana, with an empty bottle of prussic acid in her hand) to pronounce it his life's greatest "shock": "The news stunned me at the time it was told - I fell down insensate - and the memory is too painful for even a line to bewail the sacrifice. No more" (4: 375).

So the philanderer loved Landon but not as much, not nearly as much, as she loved him: "For well I know I cannot be / All thou hast made thyself to me" ("Valedictory Stanzas” 59). According to L. E. L.'s creed, Jerdan could not begin to love as she did because he lacked her powers of fantasy, and fantasy "creates" the great passions that embody great love.

It is the heart creates

Its own bliss and misery.

What must a woman feel, Whose very soul is given To that wild love - whose world must be Her all of Hell or Heaven?

Then to meet the careless smile, Look on the altered eye, 
We should also bear in mind that, as far as L. E. L. was concerned, the unfaithful man served to magnify the woman's sacrifice. The men in Landon's love poems are almost never worthy of the women who adore them, as has often been pointed out. That Jerdan "no doubt . . . was of heedless habits, no doubt . . . cared little for the cost of selfgratification, and was far too lightly guided all his life long by high and upright principles" would have (Hall, Retrospect 164), according to L. E. L.'s poetic ideals, reflected all the more gloriously on Landon's powers of fantasy and strength of ardor and devotion.

Landon's romantic faith in the literary value of her ideals would further explain why with her work she risked unravelling the web of lies she was spinning in every other aspect of her life. Glibly claiming in society that she had no wish to love a man as she had painted woman's love in her poems, Landon betrayed her poetic ideals to protect her affair with Jerdan from discovery. The love poetry was in fact disavowed as absolutely as all love affairs were denied. To possess any kind of respectability, Landon had to deceive just about everyone she encountered from the moment her affair with Jerdan began. Her observed life seemed to falsify her work, her very interest in tales of love. And against the odds she managed to continue to circulate in the same London society that was circulating scandalous rumors about her from 1826 until her departure for Africa in 1838. Meanwhile, she wrote increasingly about the deceit she perceived the whole of London society practising.

The deceitful poetess appears even less naïve when we reckon that she was granting her sexual favors to one who had both the power to give her every chance of gaining some popularity and the influence to bring her much more, if she pleased the readers he sent her way. Arguably the most powerful literary critic in 1820s London, Jerdan promoted Landon's work more than anyone else did in her lifetime and more than he did anyone else's (Pyle 110). His Gazette first published her poems in 1820, printed all of her work in the prolific years 1822 and 1823 , and continued to publish poems and untold reviews by her 
through the 1830s. From 1824 on, L. E. L.'s poetry volumes and novels thrived in the marketplace, partly on the strength of Jerdan's flattering reviews. Landon, moreover, needed Jerdan to manage all of her "business, whether literary or pecuniary," as she defended her relations with the editor in a letter to her friend Katherine Thomson. She could explain much of their interaction on the grounds of mutual economic benefit. For who else would have undertaken the "drudgery" of revising her proof sheets "but some one to whom my literary exertions could in return be as valuable as theirs to me?" (Blanchard 55-56).

Without question, having L. E. L.'s poems in its "Original Poetry" section boosted the Gazette's circulation and made money for Jerdan and his partners Colburn and Longman. Mid-1820s ads for the Gazette gave L. E. L. star billing when her poems were present in that week's issue. Otherwise, Gazette ads might not name any of the poets whose work was present in an issue, or they might not even refer to the poetry section. No other poet attracted would-be consumers like L. E. L. And she who was so famous could not fail to please when she expressed a proper feminine understanding of how worthless was literary renown compared to love, as in this 1825 "Song":

Oh, tell me not that general praise

Sheds sunlight on my name:

What has a woman's fearful heart

To do with aught like fame?

But the one charm that makes my lute

So very dear to me,

Is, that it can breathe of love!

And it can breathe to thee!

Yet the lines read quite differently if we assume that Landon is addressing the editor inclined to see her as a famous poet first, and a(nother) woman he could have sex with, second. Landon would then appear to be using the doctrine of separate spheres to suit her highly improper circumstances. She will not let her lover think she is compensated for his absence by "general praise" and popularity, the business of which her "fearful heart" depends on him to handle 
anyway. She will not let him forget that the poems keep coming and succeeding because she writes out of her passion for him.

But then, it could be said that Jerdan kept coming back to Landon for the sake of her poetry as much as his lust and love. I think Jerdan, like Landon, saw their affair as serving the higher purpose of inspiring her poetry. (Here we must straddle that short space between the sublime and the ridiculous, not leaning too far to one or the other.) Jerdan writes in his Autobiography that he found Landon "a creature of another sphere," in society "like others," but capable of "unalloyed raptures" when her "celestial" spirit had thrown her into one of her "inmost abstract and visioned moods (and these prevailed)." The moods were the product of a distinct, superior part of Landon's identity, which she disclosed to him when they were alone: "Then she was the Poet, seen and glorified in her writings." This Poet who could love as no one else could actually loved him, resulting in works that will "delight, touch, refine, and exalt the universal soul . . . so long as love and passion animate the breast of youth, so long as tenderness and pathos affect the mind of man." For Landon felt for him "a grateful and devoted attachment . . . all phases of which demonstrate and illume the origin of her productions. Critics and biographers may guess, and speculate, and expatiate for ever; but without this masterkey they will make nothing of their reveries." Jerdan is of course hinting at the affair here, as he is when he declares the "most difficult point in these memoirs" to be his two chapters on Landon, "the gifted being whose career intimately blended for nearly twenty years with my own in every intellectual and literary pursuit." He says further, "I cannot write in a language addressed to common minds or submitted to mere worldly rules." No "ordinary estimate" or "ordinary standard" will explain Landon to "those who have not poetry in their souls and warm and deep sympathies in their natures." She is "recalled through floods of unavailing tears flowing from aged eyes" (3: 168-170, 173).

Sex and sentimentality are mixed to an extraordinary degree in the Landon chapters of Jerdan's mid-Victorian Autobiography. Early in her career Landon had been mixing them more brazenly.

I'll meet thee at the midnight hour, 
When their light the stars are weeping

Like a spirit I will glide,

Softly thy dear bosom seeking,

Thou shalt bid thy fair hands rove

O'er thy soft lute's silver slumbers,

Waking sounds of song and love

In their sweet Italian numbers.

Then I'll make for thy dark hair

A coronal of moonlit roses,

Or with thy heart so near mine

That I feel its every motion,

Many wild tales shall be thine

Of the wonders of the ocean.

But when morning comes I fly,

Like the stars, away from heaven,

By those eyes of dark beauty,

The spell of that sigh;

By the blush that now burns

I would love thee as truly

As woman can love,

But I know that thy vows

Are too light to be true:

They are sweet as spring flowers,

And as perishing too!

With "I fly" the female speaker switches from the future tense to the present, indicating that she regularly comes to him at midnight and leaves at dawn, that she plans this meeting knowing well what will happen. She is full of past delights and expectation of more. Thoughts 
of his eyes, his or her sigh, and her guilty-yet-sentimental blush prompt her vow, which leads to the even more sentimental admission that his vows could never be true. The couple's sweets cannot last, but that makes them all the sweeter. His expected unfaithfulness enables the female speaker to bestow the wonders of her ocean with just enough sorrow to distract less attentive readers from the poem's innuendoes of mutually pleasing sexual intercourse. These 1823 lines were probably composed several months after Landon and Jerdan's affair had begun. That in 1823 a poet who was known to be a young single woman was able to get poems like this published in England would astound us, if it were not for the fact that her adulterous lover was her editor, and as both, he was more enamored with L. E. L.'s poetry than he -- or she -- was protective of her reputation.

19

In society, Landon was forever disobeying some or other standard of propriety. On a rebellious whim at a party in 1824, she would seem almost to have invited onlookers to imagine how many "a coronal of moonlit roses" she had made for Jerdan's "dark hair." Mary Howitt passed on the gossip to her sister in an October letter:

Didst thou know that L.E.L. was a ward of Jerdan's, the editor of the Literary Gazette? whence his abundant and extravagant puffs of her. She is . . a most thoughtless girl in company, doing strangely extravagant things; for instance, making a wreath of flowers, then rushing with it into a grave and numerous party, and placing it on her patron's head. ... [S]he is but a girl of twenty [actually twenty-two], a genius, and therefore she must be excused.

Though the Quaker poet thought such creative impulses required some latitude, she still disapproved of the behavior of the author of the (similarly unrestrained) work everyone in 1824 was talking about, The Improvisatrice; and Other Poems. Interestingly, the "fiery phraseology" of its love poetry was judged "indecorous" only by the Universal Review, whose writer yet considered Landon ignorant of the sexuality she implied (Universal Reviews emphasis; 182). The Improvisatrice's many other reviewers chose to see nothing improper - though the volume's heated passions did win L. E. L. a few nods and winks in print (Stephenson 30). 
Up until 1826, when the rumors of her affair with Jerdan arose, Landon felt somewhat free to write erotic poems in which both innocent and indecent interpretations were possible because she was protected by the common supposition of her sexual innocence. Plus, no one enjoying her improprieties was going to call attention to them, and there were probably many in this category who chose rather to applaud her femininity. Those disturbed by her loose implications could not be certain that L. E. L. knew to what misdeeds her impassioned lines pointed, and, like Howitt, they did not want to harm the development of a female widely deemed to possess exciting talent. Lacking any grounds for that certainty, the gentleman who suggested otherwise in London circles risked having his honor called into question by one of Landon's supporters. The lady who similarly faulted L. E. L. could have been judged to bear a less than pure mind.

Landon's relations with Jerdan seemed innocent enough at the start, with her parents agreeing to let their teenage daughter receive (apparently unpaid) advice and training from the editor. Jerdan fully shared Landon's yearning for glory, and for that more than any other reason she adored him at the beginning of their relationship. He was the first person in her life to think her grand ambitions worthy and attainable. Indeed, believing her talent insufficiently appreciated by her family, she could hardly have resisted falling for the busy editor willing to take time to help her become a better poet. "From day to day and hour to hour," Jerdan claims in his Autobiography, "it was mine to facilitate her studies, to shape her objects, to regulate her taste, to direct her genius, and cultivate the divine organisation of her being" ( 3 : 169). His picture of close, perhaps daily, contact can be trusted, boast though it clearly is. The editor regularly chaperoned Landon to art exhibitions and plays, most of which one of them would then review in the Gazette. He introduced her to many eighteenth- and nineteenthcentury writers, and the two often read poetry together.

In his short, anonymous "Memoir of L. E. L.," Jerdan does not dwell on his tutelage, but he does point to the early results of his taking on Landon as a pupil when he singles out a particular year and poem. One has to smile at the real probability that Jerdan had the beginning 
of their sexual affair in mind when he wrote the following: "Throughout the year 1822, L. E. L. was as full of song as the nightingale in May; and excited a very general enthusiasm by the Sapphic warmth, the mournful emotion, and the imaginative invention, the profound thought and the poetic charm with which she invested every strain" (xiii). This year Landon began to publish several series of rambling, blank-verse Poetic Sketches in the Gazette that, in their intensity, poetic faults, and waywardness gave every appearance of having been impulsively written, spun out in a flurry of passion escaped from that mysterious arena ever guessed at, the female heart. Recalling the "luxuriant grace" of the sketches which gave Landon her first taste of popularity, Jerdan is careful to identify "Sappho" as "the first of the second series . . . a remarkable example of the passionate force in which the ideas are couched ... a poem, of its order, unsurpassed in any language" (xv).

The work that was published on May $4^{\text {th }}$ is, arguably, the most important of the Poetic Sketches as Landon treats the "SapphoCorinne" myth for the first time at length, while she confirms her audacity in weaving her feelings for Jerdan into her love poetry. From the long line of poems about Sappho stretching back to Ovid, Landon makes a crucial deviation. She introduces an older man, Sappho's "first love," and attributes the magnetism of Phaon, her second and fatal love, to his resemblance to this unnamed man, who, as Sappho's former tutor, occupied a role identical to that of Jerdan vis-à-vis Landon in 1822. As Margaret Linley notes, Phaon here "becomes a mere copy of another more originary first love" (23).

Sappho is first seen alone on stage, leaning on her harp in front of "thousands" who "knelt / And worshipp'd in her presence," shed "burning tears," and paused in "breathless agitated eagerness," before shouting her name to the hills. Heightening this crowd's response beyond that of De Staël's Corinne or her own short "Corinna" (1821), L. E. L. glorifies first the assembled masses, then Sappho, for humbly adoring those they deem their superiors. The crowd finds her yet more alluring as she turns "tremulous" and full of "timid tenderness" when her eye falls on "a Youth, and other days / And young warm feelings have rushed on her soul / With all their former influence." Having 
turned from the crowd to look at Phaon, Sappho, already at "other days," has mentally turned from the youth whose features serve to open the floodgates of her memory of a tutor:

... one had called forth

The music of her soul: he loved her too,

But not as she did -- she was unto him

As a young bird, whose early flight he trained,

Whose first wild songs were sweet, for he had taught

Those songs -- but she looked up to him with all

Youth's deep and passionate idolatry:

Love was her heart's sole universe -- he was

To her, Hope, Genius, Energy, the God

Her inmost spirit worshipped -- in whose smile

Was all e'en minstrel pride held precious; praise

Was prized but as the echo of his own.

Her first love never wholly lost its power,

But, like rich incense shed, although no trace

Was of its visible presence, yet its sweetness

Mingled with every feeling, and it gave

That soft and melancholy tenderness

Which was the magic of her song. ... That Youth

Who knelt before her was so like the shape

That haunted her spring dreams - the same dark eyes,

Whose light had once been as the light of heaven!

Its first reader, Jerdan would have been more susceptible to "Sappho" than any reader since. He knew it was about him, and, rather than deterring him from publishing it, this knowledge seems to have convinced him of its unsurpassable worth. Not only did it expose in the most shameless manner Landon's idolization of him, but "Sappho" defined his affection for Landon while accepting it could not match hers. The poem even provided him with a justification for loving her. 
Upon hearing the news of Landon's death in January 1839, Jerdan would lament in a letter to the Countess of Blessington:

My poor, dear, all but adored L. E. L. -- The creature whose earliest and precocious aspirations it was mine to cherish and improve, whose mind unfolded its marvellous stores as drawn forth and encouraged by me -- well did she sweetly paint it when she said, "We love the bird we taught to sing." and truly and devotedly did I love her for fifteen eventful years. [3]

Letter to Lady Blessington

None of Landon's best known volumes of poetry contain the line Jerdan cites, and he may well be imperfectly remembering the five lines from "Sappho" that describe the tutor's feelings: "He loved her too, / . . she was unto him / As a young bird ..." etc. Regardless, the line Jerdan cites is a simplified restatement of those five lines (Landon often simplified in the process of recycling sentiments from previous poems).

26

In his Autobiography, Jerdan quotes the same line in a crucial passage following a description of how Landon responded to his tutelage:

The world was only opening and unknown to her, and she might - even holding her child-like gratitude in view - both feel and say, 'For almost every pleasure I can remember I am indebted to one friend. I love poetry; who taught me to love it but he? I love praise; to whom do I owe so much of it as to him? I love paintings; I have rarely seen them but with him. I love theatre, and there I have seldom gone but with him. I love ideas; he has conducted me to their attainment. Thus his image has become associated with my enjoyments and the public admiration already accorded to my efforts, and he must be all I picture of kindness, talents, and excellence.

At least Jerdan admits that she overestimated him, adopting Landon's theory that such overestimation displays the creative verve of the poet. For he adds that, "Gratitude is prone to such illusions, and especially where combined with the fire and fervour of genius; and if 'We love the bird we taught to sing,' how much more intensely must we cherish the love of the bird that sings in such a strain" (3: 172). Our knowledge of Landon and Jerdan's affair demands that we no longer take such passages to be the product of an old man's absurd fantasy. "He was / To her, Hope, Genius, Energy, the God / Her inmost spirit worshipped" is, after all, how L. E. L. imagines perfect love. And Sappho's love for her tutor "gave / that soft and melancholy tenderness / Which was the 
magic of her song." Thirty years before Jerdan claimed as much in his Autobiography (3: 170), Landon here asserts that a young woman's passion for an older man endowed her poetry with the depth of erotic feeling that made it popular, so that "strangers heard her name, and eyes that never / Had looked on SAPPHO, yet had wept with her" (282).

What role "Sappho" played in Jerdan and Landon's relationship is worthy of a little speculation. It came out near the time when Landon's relationship with Jerdan would cause her to move out of her parents' house and into her grandmother's. [4] Many of the poems that follow in 1822 and 1823 contain explicitly sexual overtones, the like of which Landon had not published up through the time she wrote "Sappho." More than any previous poem, "Sappho" perhaps operated as Baudrillard's "challenge" in Seduction "to love more than one is loved" in that its directness required a response (22). Through her manuscript poem, Landon telegraphed the editor that he did not appreciate the nature of her affection for him because he regarded her as a mere bird he taught. Jerdan may well have seen "Sappho" as a challenge to show her how very much he could "intensely . . cherish" the bird, just as his two citations of "We love the bird we taught to sing" are intended to show others.

Conversely, though Jerdan and Landon's sexual affair may have been helped to start by "Sappho" and similar poems, "Sappho" in particular stresses the heroine's entrapment in her yearning and visions. When Sappho sees Phaon, she falls for him "with all the ardour of a heart I Which lives but in itself," not recognizing that he presents a poor chance of her making a human connection. But then, Landon gives Sappho no chance with anyone. "A soul / So gifted and passionate as her's [sic] / Will seek companionship in vain, and find / Its feelings solitary." Eventually finding that "talents, riches, fame, / May not soothe slighted love," this woman convinced of her superior passions jumps to her death (282). I doubt that Jerdan thought he could disprove the essential bleakness of Landon's outlook or that he wanted to. Jerdan believed L. E. L.'s melancholy song called forth the best feelings of which humanity was capable, the ready sympathy for tales of woe which came from understanding that everyone suffered and the most 
attractive suffered most. That is, poetic geniuses and women. In the same 1839 letter to the Countess of Blessington - whom Jerdan flatters as "one, every emotion in whose heart is attuned to the dearest and loveliest sympathies in our Nature" - Landon's lover in effect equates Landon's life to those of her archetypal heroines:

Could her life be told what a history would be there of a woman[']s fated wretchedness and of the woes which genius must endure. A life of self-sacrifice from infancy to the grave -- of suffering. . . . Men are exposed to unhappiness, but alas what else is there for their beautiful and gentle companions? Hard is the fate of womankind; and the serpent whose curse contends with the heels of the one, gnaws the hearts and drains the lifeblood of the other.

Letter to Lady Blessington

Sacrifice and suffering help form the beauty and gentleness they eventually destroy. Yet the sympathy they evoke, like melancholy, keeps alive that desire for the dead beloved whose image is as dear to Jerdan in his 1852 Autobiography as it is in the 1839 letter.

29

Some of the literary support for Landon and Jerdan's affair beginning in 1822 comes from a few outrageous lines in "The Cup of Circe" and from "Isadore," probably Landon's first published short story. Her third poem on Richard Dagley's drawings, "The Cup of Circe" was published on August 10th, when, if Landon had not already lost her virginity, she was just about to do so. Amid its catalogue of inebriates who "all bent joyfully beneath" the "thrall" of Circe's eyes, a "white haired man" hangs on the brim of her wine goblet.

And by his side a girl, whose blue eyes, bent

On the seducer, looked too innocent

For passion's madness; -- but love's soul was there -

And for young Love what will not woman dare![5]

Jerdan's boast bears repeating that at his house "The Circean cup was gently replenished" with frequency (Autobiography 4: 16). Here, with wine and sexual lust, Landon mixes the devoted love of a "girl," a teenager, presumably. The old man looks to the wine cup to help him seduce the girl; the girl's looking on the man is meant to signal her purity. The girl, or young woman, dares to give her body to the man, 
innocent of the idea that his sexual desire could exist without love. That innocence alone makes her a victim and makes possible her virtue. The virtue of what she dares is echoed in Landon's recycling of the last of the four lines in The Vow of the Peacock (1835), when L. E. L. asks of Amenaïde, "urged by love and love's despair, / What is there woman will not dare?" (63). Amenaïde saves her beloved Leoni's life by taking the blow an assassin intended for Leoni and dying as a result. Only because Landon was writing her 1822 poem on a painting with a catalogue of characters, where the girl would be passed over too quickly to be questioned by most readers, could Landon have dared to present the girl's submission to her seducer as a comparably admirable sacrifice.

On the same page in the August 10th Gazette, two columns over, L. E. L. tells the story of a nineteen-year old Spanish woman (Landon would turn twenty on August 14th) who falls for the much older Colonel Fitzallan, for whom "the day of romance was over; a man above thirty [Jerdan was forty] cannot enter into the wild visions of an enthusiastic girl" (505). The only signed story Landon wrote for the magazine, "Isadore" is a tale of melodramatic anguish at the edge of London society. The story opens at Isadore's English graveside and then recounts how in Spain the wounded Fitzallan could only jest about being Isadore's "true and loyal knight" (504). Hoping to meet Fitzallan again in London, Isadore never gets closer than when, through her coach window, she catches sight of Fitzallan, his "delicate" wife, and his "elegant equipage" in a busy street (505). Isadore dies a rejected outsider, her story representing the first time Landon showed plainly that her tragic thrust is aimed at polite society's shallow heart.

Love purifies, Landon maintained throughout her corpus, but as early a work as "The Bayadere" (1823) indicates that this purification remains incomplete until love is proven to mean more than life. Landon took the outline of her plot from a "faint recollection" of the "tale I had either read or heard" that, unknown to her at the time of writing, came from Goethe's popular "The God and the Bayadere," which she claims not to have read in German nor in translation (The Improvisatrice 155). Like Goethe, she clearly expected her readers to be aware that dancing bayaderes sought to give themselves sexually to Brahmans 
and wealthy Hindoos. But reading Frederick Shoberl's Hindoostan (1822) made Landon appreciate that bayaderes "have nothing . . . of the nauseous boldness which characterises European prostitutes: their style of seduction being all softness and gentleness" (58).[6] Hence, Landon's bayadere lacks the "painted face" and "painted cheeks" that, in Edgar Bowring's 1797 translation, declare the "heart so corrupted" of Goethe's dancer (2-3).[7] The surprise in Landon's poem is that any "sin / Could dwell so fair a shrine within," as Mandalla sighs. Landon creates a brief funeral scene so that Mandalla, the Indian god turned Brahman, may observe

...lingering lone, --

The bayadere: her part had been

Only the hired mourner's part;

But she had given what none might buy, --

The precious sorrow of the heart.

“Part 2" 571

The bayadere lingers here as a model for sentimental readers, especially young female ones. She is also akin to the hired Landon, who liked to think her precious sorrow (but also her body) could not be bought.

To rid the bayadere of sin so she may join him in heaven, Mandalla will first show her what it is like to be "beloved in . . fond purity" through sexual intercourse ("Part 2" 571), [8] though Landon does not explicitly state that sex has occurred. The last section of the poem opens in a moonlit bower with the bayadere, full of new "tenderness," lying beside Mandalla in what is clearly post-coital bliss - but one could choose to view it otherwise for delicacy's sake.[9] "Love . . . belongs to the pretexts which sensuality finds for the disorders of desire to show them a power for good. . . . Love of the sexual partner . . . changes sexuality into tenderness; tenderness attenuates the violence of nocturnal pleasures." Georges Bataille's Eroticism thus addresses how Landon uses sentimentality to make the sexuality of her verse socially acceptable. Illustrating what Bataille calls the "ambivalence" inherent in the sexual partners' loving relationship (242), the bayadere cannot rest contented beside Mandalla but must stir up more of both of their passion. Over the course of fourteen lines Landon describes how 
"sometimes she would leave his side" to dance a shawl dance "round him," after the manner of Lady Hamilton. Bayaderes seduced their respectable prey by these private dances, Hindoostan maintains. "They give themselves great loose and ... without any exposure of the body, they are mistresses of such motions, looks and gestures, as are perhaps still more provoking" (55).[10] Coming to Hindoostan when she had probably just begun her affair with the married editor, Landon would not, I suspect, have been made a mite less enchanted with the bayaderes because they were "frequently the cause of the ruin of families" (58).

For his final lesson, Mandalla brings about the sudden death of his human body to instruct the bayadere in love's "faith, its grief, and its darker part." And she is "from thy earth stains purified" when she springs on his "burning pile to die!" Landon does not say here what qualities derive from love's "darker part," but they would seem to be the same represented by the center of the flower "found in every wreath" of the bayadere's bower of erotic love: the tulip "Whose passionate leaves with their ruby glow / Hide the heart that lies burning and black below" ("Part 3" 585). Lying latent beneath tender love would seem to be violent sexual passion, but with sentimental norms shying away from the portrayal of sexual intercourse, Landon caused her heroines to be forsaken by their lovers, bringing about the heroines' grand displays of more presentable and yet dangerous passions. Less obviously sexual, those dark passions are the jealousy, bitterness, hate, and despondency that in Landon's love stories typically culminate in the longing for death and its realization, more than seldom by suicide or murder. Those passions are the "Doubt, despairing, crime and craft, / . . upon that honeyed shaft" of the Indian cupid's arrow, which leaves "A wound, a blight, a curse, a doom, / Bowing young hearts to the tomb!" ("Manmadin" 794). As payment for love's flitting raptures, L. E. L. welcomed despair, avowing that woman's love brought her misery for which there was no solution except death. But then, as Bataille says, "Death is the symbol of all sensuality, even that modified by tenderness" (242). Probably there was no better way for Landon's sentimentality to express violent sexual passion than through the dying of a broken heart. 
Landon was reacting against conventional notions of purity in late 1822, when she first read Hindoostan (793). In "The Painter's Love" published on December $7^{\text {th }}$, the abandoned, dying female speaker thinks of her "happiness" before she knew her lover as "all too pure and passionless!" And "even now" her "pulse throbs" to remember how she exchanged that state for a fallen one full of passion, without a bride's "purest hopes to cheer / The bashfulness of maiden fear." She condemns the painter as she informs him that he has broken a "heart but sullied for thy sake" (776), yet the reader should sense that through sullying herself the painter's lover approaches the total purification death will bring. That purification requires she endure a time when

My sleeping eyes ceased not their tears;

And jealousies, griefs, hopes, and fears

Even in slumber held their reign,

And gnawed my heart, and racked my brain!

Oh much, -- most withering 'tis to feel

The hours like guilty creatures steal,

To wish the weary day was past,

And yet to have no hope at last!

All's in that curse, aught else above

That fell on me - betrayed love! - - -

I must rest here - Oh lay me then

By the white church in yonder glen....

Behind almost all of Landon's love poems lies the belief in what she terms in The Lost Pleiad (1829) "That pure, that high, that holy creed, / Without which love is vain indeed" (The Venetian Bracelet 56). Again and again, the fictional adherents to her creed prove not only their willingness but desire to die for love. Fully aware of its dark origins, Landon yet saw this desire to die as a final step toward freeing oneself from the earthly, the selfish in or out of love -- from all that is not selfsacrificing. 
What a far cry from love's purification were the 1826 scandals in the press. I think the first report was published on 5 March 1826 in the Sunday Times under the heading, "Sapphics and Erotics":[11]

A well-known English Sappho ... famous for the amorous glow of her fancy, has just been detected in a faux pas with a literary man, the father of several children. The discovery happened when the placens ... and brats were sent off . . . last September to the waterside, and was effected by means of a charwoman. ... Observing, that as often as the youthful Sappho arrived at the embowered recess of Love and the Muses, the blinds on the ground-floor study were pulled down and shutters pulled up; and wondering how books could be read in the dark, this female busybody stationed herself so ingeniously . . . as to see the whole poetical mystery, by which 'hearts throb with hearts,' and 'souls with souls unite.' This she expounded to the wife. . . Other truths then came out, from which it appeared that the 'virgin gentleness, the orphan muse' [Landon's father died in 1824] had honored her Benedict (though not Benedictus) Phaon with a young chubby Terpander, or son of a /yre, two years before, and at Canterbury of all places.

Sunday Times' emphasis

Though no names were supplied, the identities were all too easy to guess in 1826, shortly after Landon had scored her second publishing triumph with The Troubadour (1825) and at a time when the Sunday Times was far more interested in gossiping about Landon than any other woman poet.[12] I suspect "Sapphics and Erotics" is mostly or at least partly true. Those moments "When dearest eyes gaze with us on the page / Bearing the poet's words of love" must have so spiced Landon and Jerdan's literary study that one wonders how the couple ever managed to read anything but "words of love" when together or, more to the point, how they managed to read at all (The Improvisatrice 134). In my biography of Landon I hope to have space to deal with the many factual questions this and other scandalous reports throw up. Suffice it to say here that the Sunday Times got the birthdate of Landon and Jerdan's first baby about right, though not the gender.

When Landon's friend Katherine Thomson claims in The Queens of Society (1860) that the Sun newspaper made the first assault on L. E. L.'s reputation in the mid 1820 s, a distance of more than thirty years has probably helped her to confuse the Sun with the Sunday Times.[13] I have found nothing scandalous about Landon in my perusal of all the issues of the 1825 and 1826 Sun. And the year of the first assault must have been 1826 because Landon's letter to Thomson, dated June 1826 and published in Blanchard's memoir, 
makes plain that she had never experienced attacks on her reputation until very recently. By June, attacks had also appeared in three different issues of the Ass that named the poet and the editor and parodied Landon's love poems (Lawford 37). The Ass picked up the rumor of the Landon-Jerdan affair on its first day of its publication, April 1st, which the Sunday Times ungentlemanly acknowledged on April 2nd: "The new publication called The Ass, in a letter to Mr. William Jerdan of the Literary Gazette, says, he has ... given [']the finishing stroke of inspiration to Miss Landon.' -- Is this banter or compliment?" (Sunday Times' emphasis). I doubt many of its readers thought the Sunday Times really considered the Ass's innuendo to be good-humored banter, much less compliment.

"As to the report you named, I know not which is greatest -- the absurdity or the malice." Thus Landon, in her June 1826 letter to Thomson, disdained the rumors of illicit relations with "the gentleman" to whom she is "very much indebted ... . for much of kindness" (Landon's emphasis; Blanchard 55). But her affected disdain did not hide her "bitterness and indignation. . . I I think of the treatment I have received until my very soul writhes under the powerlessness of its anger." Landon was most upset by the effect the rumor was having on how her work was perceived. Evidently anticipating Thomson will show this letter to others, Landon stood up for

the only thing in the world I really feel an interest in -- my writings. . . When my 'Improvisatrice' came out, nobody discovered what is now alleged against it . I did not take up a review, a magazine, a newspaper, but if it named my book it was to praise 'the delicacy,' 'the grace,' 'the purity of feminine' it displayed. . . . With regard to the immoral and improper tendency of my productions, I can only say it is not my fault if there are minds which, like negroes, cast a dark shadow on a mirror, however clear and pure in itself. You must forgive this; I do not often speak of my own works, and I must say this was the first time it was ever done boastingly; but I must be allowed to place opinions of the many in opposition to the envious and illiberal cavillings of a few.

It is a wonderfully shallow defense, as thin as the mirror she turns on those who find the "fault" for which she refuses to take responsibility. Landon gives Thomson no personal insight into her work. She just maintains that the Improvisatrice; and Other Poems was praised fairly, that all of her poems are "clear and pure." Yet the defense satisfied 
Thomson (and many other friends). In The Queens of Society, Thomson derides the "host of almost invisible slanderers who found delight in bringing down to the vulgar level of their own minds one all genius and purity" (205). In her earlier Recollections (1854), she addresses them with righteous indignation: "Ye, who could convert the carelessness of an occupied and innocent mind into proofs of guilt, be satisfied with this - the arrow sped - the wound it made was a festering and deadly wound, and was never, never healed" (83).

Landon does not deceive Thomson by her confidence in the moral value of "the only thing in the world I really feel an interest in," the poems which contain the most honest, sensual, and idealistic words she ever wrote. Instead, she deceives her friend of many years by pretending to speak the same language when she is well aware that Thomson, with her "high sense of moral rectitude," defines the feminine ideals of the day differently (Blanchard 53). Landon deceives by accepting as accurate the most idealized opinions of her reviewers, although Thomson does not require this kind of absolutism of her: "You must forgive this." Feeling backed into a corner by the attacks, Landon yet remains uncomfortable with speaking "boastingly" to a friend who trusts her. She perhaps senses that she does not need to play the language game she is nevertheless playing with Thomson, who many years later would admit she did "not believe that she [Landon] cared about me" (Recollections 76).

Landon used her letter to Thomson to defend herself to the public and in the process exploited and betrayed their friendship. Landon knew Thomson did not think she was having an affair with Jerdan, but she would "express my surprise at so cruel a calumny" being perpetuated when her "intercourse" (yes, that is her word) with Jerdan has been so "slight": "He is in the habit of frequently calling on his way into town, and unless it is on a Sunday afternoon, which is almost his only leisure time for looking over letters, manuscripts, \&c., five or ten minutes is the usual time of his visit. We visit in such different circles, that . . . I cannot recall our ever meeting in any one of the round of winter parties" (Blanchard 55). If Landon and Jerdan were discovered by the charwoman in September 1825, then it would stand to reason they 
would have taken the precaution of no longer attending the same parties nor being with each other under observation for more than a few minutes. Landon does admit in the letter that Jerdan was still stopping by "frequently," when her grandmother would likely have been present. But what she says is meant only to distract from what she does not say: when she and Jerdan meet privately. The poet acts as if such things as secret meetings at midnight never entered the mind of one who made them almost a staple of her love stories.

In my London Review of Books article, I did not mention another letter to Thomson, which, if true, falsifies the Wasp's announcement of 7 October 1826 that the formerly pregnant-looking Landon, having been absent for months in Aberford, had just "returned" to the London area "as thin and poetical as ever" ("Quacks" 22). "Written expressly for my own amusement" from Biggleswade, Landon's late October letter describes to Thomson how she travelled "in the mail" coach from Aberford to Royston, near Biggleswade. (Landon remained in Biggleswade until late December, not showing her face in London until the Wasp attack was a few months' old.) It would at first seem that the scandal sheet writer was lying about having seen Landon in the London environs because according to her October letter she did not return to London after leaving Aberford. But in her June 1826 letter Landon lied to Thomson, so she may well have lied in the October letter too. A letter to a different friend from Aberford postmarked 5 September 1826 states that she will be staying there "some more" weeks and does "not know at all when I return to town" (Letter to Emma Rich). Landon gives the impression she will be coming straight back to London, saying nothing about going anywhere else, which leaves open the possibility that Landon did return for a brief stay at roughly the time the Wasp writer claims. The October $7^{\text {th }}$ attack was succeeded by that of the October $14^{\text {th }}$ issue, in which L. E. L. was "charged with having written a sentimental elegy on the Swellings of Jordan. She pleaded that the flood had gone off, but the plea was overruled; and she was ordered into the country to gather fruit, and to deliver an account thereof on her return" (Wasp's emphasis; "Retributive Term" 36). An actual sighting of Landon could have produced the October $7^{\text {th }}$ attack, which then caused her to leave London again immediately, so as not to have her slimmer self 
subjected to continual examination. The October $14^{\text {th }}$ attack could then, with slightly different meanings, refer to a second visit to the English countryside, and Landon might well have intended that her October letter to Thomson cover her tracks.

41

We deal in shadows here, able only to speculate over so many details -- whether, for instance, a baby named Fred Stuart was in Biggleswade. However, if the truth of Landon's life and death must be guessed at, we would seem better served by looking not to Landon's letters but to L. E. L.'s love poems and rumors in the papers. At least Landon revealed to a few friends how disturbed she was by the damaging gossip in the press. William Howitt gives a second-hand report of Landon's reaction to an 1830s scandal:

During the agonies of mind which Miss Landon suffered, at a time when calumny was dealing very freely with her name, her old friend, and for a long time, co-inmate, Miss Roberts came in one day, and found her very much agitated. 'Have those horrible reports, she eagerly inquired, 'got into the papers, Miss Roberts?' Miss Roberts assured her they had not. 'If they do,' she exclaimed, opening a drawer in the table, and taking out a vial, 'I am resolved -- here is my remedy!' The vial was a vial of prussic acid. This fact I have on the authority of the late Emma Roberts herself.

This is the same Emma Roberts who, in her memoir of Landon, is certain that her infamous death in Africa was "wholly accidental" (31). And this is the same William Howitt who, while admitting "the perpetual creed of L. E. L., that all affection brings woe and death" (136-37), continues to "cling" to "the belief . . . that L. E. L. . . . died so by accident" (141). Taken together, a significant number of Landon's works published throughout her career demand that we suspect suicide.

The love poetry is authenticated by the poet's experience. It is time we trusted her poems, giving their loves and deaths the weight of feeling that is due great sacrifices, especially sentimental ones that ask for sorrow and tears. The loss of individuality that those overwhelming expressions require seems, after all, not too many steps away from that turbulent loss of individuality which Bataille taught us is at the heart of sexual ecstasies and death throes. Justified by the high stakes 
at play in Landon's secret affair with Jerdan, L. E. L.'s passionate line deserves and, if it is to do more than impress, requires that sympathizing trust. The beauty and glory she envisioned in woman's sacrificial love motivated her to risk everything to act on her passion for Jerdan, above all, three pregnancies and childbirths, and to write out her heart's impressions in splendid fervour. Her heroines' deaths do not implode her ideals of woman's love. Rather the deaths realize these ideals by confirming her repeated view that the love she portrays is too fine for this world. Landon's poetry can still take readers, if we let ourselves follow her reckless lead, to outposts of erotic absorption and disillusionment where forsaken bodies are torched for the magnificence of the burning. Such uncompromising territories we might otherwise never traverse.

Bataille, George. Eroticism. Trans. Mary Dalwood. 1962. London: Penguin, 2001.

Baudrillard, Jean. Seduction. 1979. Trans. Brian Singer. London: Macmillan, 1990.

Blanchard, Laman. Life and Literary Remains of L. E. L. Vol. 1. London: Henry Colburn, 1841. 2 vols.

De Staël, Madame [Germaine]. Corinne; or Italy. Prose trans. Isabel Hill. Poetry trans. Letitia Landon. London: Richard Bentley, 1833.

Duncan, Robert Wayne. "William Jerdan and the Literary Gazette." Diss. U. of Cincinnati, 1955.

Goethe, Johann Wolfgang von. "The God and the Bayadere." Poems of Goethe. Trans. Edgar Alfred Bowring. 1797. www.everypoet.com/archive/poetry/Goethe/goethe_the_god_and_the_ba vadere.htm. 1-5.

Greer, Germaine. Slip-Shod Sibyls: Recognition, Rejection and the Woman Poet. London: Viking, 1995.

Hall, Samuel Carter. A Book of Memories of Great Men and Women of the Age, From Personal Acquaintance. 1871. 2nd ed. London: Virtue, 1877. 
- Retrospect of a Long Life: From 1815 to 1883. Vol. 1. London: Richard Bentley, 1883. 2 vols.

Hawthorne, Nathaniel. The English Notebooks. Ed. Randall Stewart. London: Oxford University Press, 1941.

Howitt, Mary. An Autobiography. Ed. Margaret Howitt. London: Isbister, 1891.

Howitt, William. Homes and Haunts of the Most Eminent British Poets. Vol. 2. London: Richard Bentley, New Burlington Street, 1847. 2 vols.

Jerdan, William. Autobiography, with his Literary, Political, and Social Reminiscences and Correspondence During the Last Fifty Years. 4 vols. London: Arthur Hall, Virtue, 1852-53.

—. Letter to Lady Blessington [Marguerite Gardiner]. 5 Jan. [1839]. Ms. Add. 43688, f.64-65. The British Library.

[-]. "Memoir of L. E. L." Romance and Reality. 1831. Standard Novels No. 111. London: Richard Bentley, 1848. vii-xxii.

[Landon, Letitia E.] L. E. L. "The Bayadere: An Indian Tale. [Part 1]." Literary Gazette 30 Aug. 1823: 556.

[-] - "The Bayadere: An Indian Tale. Part 2." Literary Gazette 6 Sept. 1823: 571.

[—] - "The Bayadere: An Indian Tale. Part 3." Literary Gazette 13 Sept. 1823: 585.

[—] - - "Ci-Devant!" New Monthly Magazine 17 (1826): 3132.

[-] - "Corinne at the Cape of Misena." The Amulet; $A$ Christian and Literary Remembrance. Ed. S. C. Hall. London: Frederick Westley and A. H. Davis, 1832 [1831]. 251-55.

[- ] - "The Cup of Circe." Literary Gazette 10 Aug. 1822: 504.

[- ] - Francesca Carrara. Vol. 3. London: Richard Bentley, 1834. 3 vols.

[- ] - The Improvisatrice; and Other Poems. London: Hurst, Robinson, 1824.

[—] - _ "Isadore." Literary Gazette 10 Aug. 1822: 504-05. 
- Letter to Edward Bulwer Lytton. [January 1837]. Ms. D/EK C1/92. Lytton Papers. Hertfordshire Archives and Local Studies, Hertford.

—. Letter to Emma Rich. [4?] September 1826. Ms. Cited with the permission of Rare Books and Manuscripts, Special Collections Library, the Pennsylvania State University Libraries.

[—] - "Louise, Duchess of La Valliere." Fisher's Drawing Room Scrap-Book. 1839. London: Fisher, [1838]. 18-20.

[-] - "Manmadin, the Indian Cupid, floating down the Ganges." Literary Gazette 14 Dec. 1822: 793-94.

[—] - "The Painter's Love." Literary Gazette 7 Dec. 1822: 776-77.

[—] - _ . "Sappho." Literary Gazette 4 May 1822: 282.

[—] - - "The Stars." Literary Gazette 30 Oct. 1824: 701.

[—] ] - "Song." Literary Gazette 29 March 1823: 203-4.

[—] - _ . "Song." Literary Gazette 27 Aug. 1825: 557.

[—] - - "Stanzas." Literary Gazette 12 March 1825: 173.

[—] - _ "Valedictory Stanzas." Literary Gazette 22 Jan. 1825:

59.

[-] - The Venetian Bracelet, The Lost Pleiad, A History of the Lyre, and Other Poems. London: Longman, 1829.

[- ] - The Vow of the Peacock, and Other Poems. London: Saunders and Otley, 1835.

Lawford, Cynthia. "Diary." London Review of Books 21 Sept. 2000: 3637.

Leighton, Angela. Victorian Women Poets: Writing Against the Heart. London: Harvester Wheatsheaf, 1992.

Linley, Margaret. "Sappho's Conversions in Felicia Hemans, Letitia Landon, and Christina Rossetti." Prism(S): Essays in Romanticism 4 (1996): 15-42. 
Lootens, Tricia. "L. E. L. and Poetess Tradition." Romanticism and Women Poets: Opening the Doors to Reception. Lexington: University Press of Kentucky, 1999. 242-59.

Mellor, Anne K. Romanticism and Gender. London: Routledge, 1993.

"Odds and Ends." Sunday Times 8 Jan. 1826: N. pag.

"Odds and Ends." Sunday Times 19 March 1826: N. pag.

“Odds and Ends." Sunday Times 13 Aug. 1826: N. page.

Pyle, Gerald Jackson. "The Literary Gazette under William Jerdan." Diss. Duke University, 1976.

"Quacks of the Day. No. 2. William Jerdan." Wasp 14 Oct. 1826: 2023.

"Retributive Term." Wasp 7 Oct. 1826: 35-37.

Rev. of The Improvisatrice. Universal Review 2 (1824): 176-82.

Roberts, Emma. Memoir. The Zenana and Minor Poems of L. E. L. London: Fisher, [1839]. 5-33.

“Sapphics and Erotics." Sunday Times 5 March 1826: N. page.

Shoberl, Frederic, ed. Hindoostan, Containing a Description of the Religion, Manners, Customs, Trades, Arts, Sciences, Literature, Diversions, \&c. of the Hindoos. The World in Miniature. Vol. 3. London: R. Ackermann, [1822]. 6 vols.

Stephenson, Glennis. Letitia Landon: The Woman Behind L. E. L. Manchester: Manchester University Press, 1995.

[Thomson, Katherine] Grace and Philip Wharton. The Queens of Society. Vol. 1. London: James Hogg, [1860]. 2 vols.

- Recollections of Literary Characters and Celebrated Places. Vol. 2. London: Richard Bentley, 1854. 2 vols.

[1] Those who wish to review my full argument, plus all the available facts on Landon's early work (1820 to early 1823) and her life from birth until she had become an established writer on the Gazette, should see my Spring 2001 dissertation for the City University of New York, "The Early Life and London Worlds of Letitia Elizabeth Landon, A Woman Poet Performing in an Age of Sentiment and Display." 
[2] From the documents he has reviewed, Pyle can attest that Jerdan had a dozen or more other children, at least five of them before 1847. Jerdan would desert Frances between 1847 and 1854 and marry again, it seems, before Frances died (252-53). "Although no one accuses him of it, the available facts strongly imply bigamy" (247).

[3] I cannot as yet determine whether Lady Blessington knew the truth, as opposed to the rumor, of Landon and Jerdan's affair. Jerdan's 1839 letter is sufficiently vague to have kept her in the dark. On the other hand, his precise numbering, "fifteen eventful years," could well refer to the length of the affair, beginning in 1822 and ending in 1837, around the time of Landon's engagement to George Maclean.

[4] See chapter four of my dissertation, in which Landon's break with her mother is examined. I also discuss Landon's several poems from this period that treat daughters' guilt over leaving their fathers.

[5] Unable as yet to see a copy of this drawing, I can only expect that Dagley drew such an old man and young girl, though he might not have. But at least we know Letitia Landon spelled out the girl's inclinations - and, more outrageously, justified them.

[6] Landon obviously had Hindoostan in mind when she wrote "The Bayadere" because the Indian Cupid Camdeo, or Manmadin, who is portrayed in Hindoostan and who inspired her poem "Manmadin" (1822), likewise appears in the first part of "The Bayadere" to bring the dream "of love and woman's power, / To Mandalla's sleeping hour" (556).

[7] I am indebted to Steven Willett for finding an old translation of Goethe's ballad for me.

[8] In her discussion of The Venetian Bracelet (1829), Greer makes astute observations on Landon's value system: "Purity means for her not freedom from any taint of carnality but from any sordid considerations of convenience or social utility. The sensuous trappings of her settings, the numerous perfumed couches whereupon her lovers fling themselves when their strength fails, insist upon sensuality as an ultimate value" (308).

[9] Oblivious to such delicacy, Goethe shows the bayadere transformed by "feeling love's sharp pangs and blisses" in sexual activity so that she thinks of herself as a joyous "spouse" (3). He spares no thought for a list of the qualities of love which Landon makes her bayadere acquire to complete her purification. Furthermore, Goethe's bayadere learns nothing from her lover's death that she has not learned from sex with him. Her jumping on his funeral pyre proves merely that she has left sin behind to become a wife.

[10] From De Staël's Corinne Landon may have first learned of the Indian female dancers, with whom Corinne's dancing is compared:

Her gestures displayed that easy union of modesty and voluptuousness, such as must have so awed the Indians when the Bayardères - poets of the dance - depicted the various passions by characteristic 
attitudes. Corinne was so well acquainted with antique painting and sculpture, that her positions were so many studies for the votaries of art. . . . Corinne as thoroughly infected the spectators with her own sensations as she did while extemporising poetry, playing on her lyre.

[11] I am indebted to David Latané for finding this paragraph in the Sunday Times, which I did not know about at the time I wrote the short article published in the London Review of Books.

[12] The newspaper remarks on matters such as her uncle's position in the Anglican Church and how the Panic of 1826 might have affected her financial situation ("Odds and Ends" 13 August; 19 March). Moreover, the French poet Delphine Gai is called "the fair Sappho, and L. E. L. of Parisian circles" (“Odds and Ends" 8 Jan.).

[13] That Jerdan had acrimoniously left his job at the Sun might have made that newspaper's name stick in Thomson's memory. It is far less likely that Thomson would have confused the Sun with scandal sheets like the Ass or the Wasp 